\title{
PENGARUH MODEL STUDENT FACILITATOR AND EXPLAINING BERBANTUAN MEDIA VISUAL NON PROYEKSI TERHADAP KOMPETENSI PENGETAHUAN IPA
}

\author{
Ana Saisabila ${ }^{1}$, I Kt Ardana ${ }^{2}$, Gst. Ngr. Sastra Agustika ${ }^{3}$ \\ 1,2,3 Jurusan Pendidikan Guru Sekolah Dasar, FIP \\ Universitas Pendidikan Ganesha \\ Singaraja, Indonesia \\ e-mail: ana.saisabila@undiksha.ac.id ${ }^{1}, \underline{\text { kiktut.ardana @ undiksha.ac.id }{ }^{2}, \text { gn.sastra.a@undiksha.ac.id }^{3}}$
}

\begin{abstract}
Abstrak
Penelitian ini bertujuan untuk mengetahui pengaruh dan efektivitas model pembelajaran student facilitator and explaining berbantuan media visual non proyeksi terhadap kompetensi pengetahuan IPA siswa kelas IV SD Gugus Letda Made Putra Denpasar Utara tahun ajaran 2017/2018. Jenis penelitian ini ialah kuasi eksperimen dengan rancangan kelompok non-ekuivalen. Populasi penelitian ini adalah 11 kelompok kelas IV SD Negeri Gugus Letda Made Putra Denpasar Utara yang berjumlah 393 siswa. Teknik pengambilan sampel pada penelitian ini menggunakan teknik sampel kelompok. Sampel dalam penelitian ini terdiri dari 2 kelompok yaitu kelompok eksperimen dan kelompok kontrol. Masing-masing kelompok diberikan pre-test dan diuji menggunakan uji-t untuk mengetahui kesetaraan kelompok. Data kompetensi pengetahuan IPA diperoleh melalui tes, tes yang digunakan adalah tes pilihan ganda biasa. Setelah diperoleh data post-test kompetensi pengetahuan IPA selanjutnya dianalisis dengan uji-t menggunakan rumus polled varians. Rata-rata skor post-test siswa pada kelompok eksperimen yaitu sebesar 75,37 dan rata-rata siswa pada kelompok kontrol sebesar 68,25. Berdasarkan taraf signifikansi $5 \%$ dan $\mathrm{dk}=71$ diperoleh harga $t_{\text {hitung }}=2,147>\mathrm{t}_{\text {tabel }}=$ 1,994. Hal ini membuktikan bahwa terdapat perbedaan yang signifikan kompetensi pengetahuan IPA antara kelompok eksperimen dan kelompok kontrol. Dengan demikian dapat disimpulkan bahwa model pembelajaran student facilitator and explaining berbantuan media visual non proyeksi berpengaruh secara signifikan terhadap kompetensi pengetahuan IPA siswa kelas IV SD Gugus Letda Made Putra Denpasar Utara tahun ajaran 2017/2018. Perhitungan efektivitas model terhadap kompetensi pengetahuan IPA dilakukan dengan menghitung Koefisien Cohen's d, diperoleh nilai $d=$ 0,51 dengan kategori efek sedang.
\end{abstract}

Kata-kata kunci: student facilitator and explaining, visual non proyeksi, kompetensi pengetahuan IPA

\begin{abstract}
This study aims to determine the influence and the effect size of student facilitator and explaining learning model, assisted by non-projection visual media toward the science knowledge competences of fourth grade students at SD Gugus Letda Made Putra North Denpasar 2017/2018 academic year. The type of this research is quasi experimental with non-equivalent control group design. The population of this research was 11 group classes of fourth grade students at SD Gugus Letda Made Putra North Denpasar which amount to 393 students. The sampling technique used in this research is the group sample technique. The sample of this study was consist of 2 groups; experimental group and control group. Each group was given a pre-test and then measured by using the t-test to determine its equality. The data of science knowledge competences were obtained through a test of multiple choice questions. After obtaining the post-test data of science knowledge competences, the data were analyzed by using t-test with polled variance formula. The average posttest score of the students in the experimental group is 75,37 and the average student in the control group is 68,25 . Based on the $5 \%$ of significance level and the $d k=71$, the result obtains the $t_{\text {count }}=$ $2,147>t_{\text {table }}=1,994$. Thus, there is a significant difference of science knowledge competences between the experimental group and the control group. It can be concluded that student facilitator and explaining learning model assisted by non-projection visual media has a significant influence toward science knowledge competences of fourth grade students at SD Gugus Letda Made Putra Nort Denpasar 2017/2018 academic year. The calculation of the effect size model to science knowledge competences is done by calculating the Cohen's $d$ Coefficient, which obtains value $d=0,51$ with medium effect category.
\end{abstract}


Keywords: student facilitator and explaining, non-projection visual, science knowledge competence

\section{Pendahuluan}

Manusia membutuhkan pendidikan dalam hidupnya. Pendidikan merupakan hak asasi yang dimiliki oleh setiap orang. Pendidikan merupakan investasi yang paling utama bagi setiap bangsa, terlebih lagi bagi bangsa yang sedang berkembang. Pendidikan diharapkan dapat mengembangkan potensi siswa agar bermanfaat bagi lingkungan maupun bagi dunia pendidikan. Hamalik (2014:3) menyatakan "pendidikan adalah suatu proses dalam rangka mempengaruhi peserta didik supaya mampu menyesuaikan diri sebaik mungkin dengan lingkungannya, dan dengan demikian akan menimbulkan perubahan dalam dirinya yang memungkinkannya untuk berfungsi secara adekwat dalam kehidupan masyarakat". Oleh karena itu, pendidikan memiliki peran yang sangat penting dalam meningkatkan sumber daya manusia yang berkualitas

Sejalan dengan pentingnya pendidikan mendorong berbagai pihak untuk melakukan upaya agar pendidikan khususnya pendidikan Indonesia semakin maju, salah satu cara yang dapat dilakukan adalah dengan mengembangkan Kurikulum. Mengacu pada Kurikulum 2013 yang menggunakan pendekatan saintifik, maka yang menjadi pembelajaran di sekolah dasar saat ini adalah pembelajaran tematik dengan menggunakan pendekatan saintifik. Menurut Kosasih (2014:72) "pendekatan saintifik merupakan pendekatan di dalam kegiatan pembelajaran yang mengutamakan kreativitas dan temuan-temuan siswa". Pendekatan saintifik meliputi lima pengalaman belajar yaitu mengamati, menanya, mengumpulkan informasi, mengasosiasikan dan mengomunikasikan. Proses dan pengalaman belajar yang diperoleh tersebut harus pula menyentuh tiga ranah, yakni ranah kompetensi sikap, pengetahuan, dan keterampilan.

Kurikulum saat ini memfokuskan pada pemerolehan kompetensi-kompetensi tertentu oleh siswa, salah satunya kompetensi pengetahuan. Kompetensi pengetahuan merupakan kemampuan yang menuntut pemahaman sejumlah konsep dan informasi yang harus dimiliki dan dikuasai oleh siswa melalui kegiatan pembelajaran serta dinyatakan dalam suatu nilai tertentu. Salah satu muatan materi pembelajaran pada jenjang pendidikan Sekolah Dasar (SD) dalam Kurikulum 2013 yaitu muatan materi IPA. "Sains atau IPA merupakan usaha manusia dalam memahami alam semesta melalui pengamatan yang tepat pada sasaran, serta menggunakan prosedur, dan dijelaskan dengan penalaran sehingga mendapatkan suatu kesimpulan" (Susanto, 2013:167). Menurut Wisudawati dan Sulistyowati (2014:22) "IPA merupakan ilmu yang pada awalnya diperoleh dan dikembangkan berdasarkan percobaan (induktif) namun pada perkembangan selanjutnya IPA juga diperoleh dan dikembangkan berdasarkan teori (induktif)". IPA menurut hakikatnya merupakan ilmu yang berisi pengetahuan tentang alam semesta dengan segala isinya (Samatowa, 2016). Pembelajaran IPA di Sekolah Dasar sebaiknya dilakukan secara aktif untuk menumbuhkan kemampuan berpikir dan bersikap ilmiah.

Berdasarkan informasi yang diperoleh di SD Gugus Letda Made Putra Kecamatan Denpasar Utara dengan ketua gugus, kepala sekolah dan beberapa guru wali kelas IV terdapat temuan berkaitan dengan pembelajaran pada muatan materi IPA, yaitu kurangnya pemahaman siswa terhadap materi serta minimnya partisipasi siswa dalam bertanya maupun mengemukakan pendapatnya (mengomunikasikan). Siswa cenderung menerima materi yang ada tanpa menyikapinya dengan kritis dan siswa jarang menerima informasi lain melalui pendapat atau pertanyaan teman sebagai penggali informasi. Beberapa faktor yang teridentifikasi sebagai penyebab terjadinya permasalah tersebut yaitu, dalam pelaksanaannya pembelajaran kurang mampu mengembangkan kemampuan berpikir siswa. Pembelajaran cenderung berpusat pada guru dan penyampaian materi dalam buku teks saja, sehingga sulit untuk memungkinkan siswa untuk mengembangkan kecakapan berpikir serta kecakapan beradaptasi dengan baik.

Guru yang profesional harus mampu menggeser paradigma pembelajaran yang lebih banyak pada kegiatan guru mengajar menjadi berorientasi pada aktivitas belajar siswa. Pembelajaran yang dilakukan harus dapat memungkinkan guru dan siswa bersama-sama 
mengembangkan kreativitas. Pembelajaran secara aktif harus dapat memicu suasana pembelajaran sedemikian rupa sehingga para siswa terlibat aktif baik dalam bertanya maupun mengemukakan gagasannya. Oleh karena itu kegiatan pembelajaran harus diarahkan agar dapat menumbuhkan keaktifan siswa, menimbulkan rasa ingin tahu dan juga kreativitas dalam menemukan sesuatu dalam pembelajaran khususnya berkaitan dengan muatan materi IPA. Selain itu diperlukan suatu upaya untuk dapat merangsang kompetensi pengetahuan IPA. Salah satunya adalah mengemas pembelajaran yang inovatif, yaitu melalui penggunaan model dan media pembelajaran yang tepat untuk mengoptimalkan proses pembelajaran dengan penyajian materi yang menarik dan lebih banyak melibatkan siswa. Salah satu model pembelajaran yang relevan untuk hal tersebut adalah model pembelajaran student facilitator and explaining berbantuan media visual non proyeksi.

"Model pembelajaran student facilitator and explaining ini merupakan model pembelajaran yang melatih siswa untuk dapat mempresentasikan ide dan gagasan mereka kepada teman-temannya" (Kurniasih dan Sani, 2016:79). Menurut Shoimin (2014:183) "model pembelajaran student facilitator and explaining merupakan salah satu tipe pembelajaran kooperatif yang menekankan pada struktur khusus yang dirancang untuk mempengaruhi pola interaksi siswa dan memiliki tujuan untuk meningkatkan penguasaan materi”. Melalui model pembelajaran ini siswa diberi kesempatan untuk menjadi seorang guru yang bertugas menjelaskan kembali isi materi pembelajaran setelah guru menyajikan atau mendemonstrasikan garis-garis besar materi pembelajaran.

Model pembelajaran student facilitator and explaining ini lebih efektif bila didukung dengan penggunaan media pembelajaran yang inovatif. Musfiqon (2012:28) menyatakan bahwa "media pembelajaran dapat didefinisikan sebagai alat bantu berupa fisik maupun non fisik yang sengaja digunakan sebagai perantara antara guru dan siswa dalam memahami materi pembelajaran agar lebih efektif dan efesien". Salah satu media yang cocok dan dapat mendukung model pembelajaran student facilitator and explaining yaitu media visual non proyeksi. Media visual non proyeksi merupakan salah satu dari jenis media pembelajaran visual (melalui indera pengelihatan), hanya saja dalam penggunaanya media ini berprinsip sederhana dan tidak membutuhkan alat proyektor. Menurut Wati (2014) terdapat beberapa jenis media visual non proyeksi yang sering digunakan dalam pembelajaran seperti benda nyata, model, media cetak, dan media grafis. Melalui penggunaan media visual non proyeksi ini dapat menerjemahkan sesuatu yang awalnya bersifat abstrak bagi siswa menjadi lebih nyata sehingga mempermudah dalam memahami suatu materi yang dibelajarkan.

Model pembelajaran student facilitator and explaining berbantuan media visual non proyeksi dapat meningkatkan pemahaman siswa terhadap materi pembelajaran, membantu mengaktifkan siswa melalui kegiatan demonstrasi serta materi yang disampaikan menjadi lebih jelas dan nyata. Hal ini tentu dapat mengatasi kesulitan-kesulitan dalam proses pembelajaran seperti sikap siswa yang kurang aktif, komunikasi dalam belajar, dan keterbatasan fisik kelas sehingga diperoleh hasil yang lebih optimal dalam pembelajaran.

Berdasarkan uraian tersebut, maka dikaji lebih luas dalam sebuah penelitian berjudul pengaruh model pembelajaran student facilitator and explaining berbantuan media visual non proyeksi terhadap kompetensi pengetahuan IPA siswa kelas IV SD Gugus

Letda Made Putra Kecamatan Denpasar Utara tahun ajaran 2017/2018. Adapun tujuan dari penelitian ini adalah untuk mengetahui pengaruh dan efektivitas model pembelajaran student facilitator and explaining berbantuan media visual non proyeksi terhadap kompetensi pengetahuan IPA siswa kelas IV SD Gugus Letda Made Putra Kecamatan Denpasar Utara tahun ajaran 2017/2018.

\section{Metode}

Penelitian dilakukan pada kelas IV SD Gugus Letda Made Putra Kecamatan Denpasar Utara. Pelaksanaan penelitian ini dilakukan pada semester 2 tahun ajaran 2017/2018. Waktu penelitian dilaksanakan pada bulan Desember 2017 sampai dengan Mei 2018 yang diawali dengan kegiatan observasi hingga penyusunan skripsi selesai. Penelitian ini termasuk jenis penelitian eksperimen dengan pendekatan atau rancangan eksperimen kuasi (QuasiExperimental Design). Pemilihan subjek dalam rancangan ini tidak selalu dapat dilakukan 
secara random, dan tidak memilih subjek sesuai dengan rancangan random, akan tetapi peneliti menerima kelas atau kelompok subjek yang telah ditentukan oleh sekolah dan kebijakan sekolah (Setyosari, 2015). Bentuk rancangan eksperimen kuasi yang digunakan adalah rancangan kelompok non-ekuivalen. Rancangan yang digunakan melibatkan dua kelompok kelas yaitu kelompok kelas eksperimen dan kelompok kelas kontrol. Kelompok kelas pertama merupakan kelas eksperimen yang mendapatkan perlakuan model pembelajaran student facilitator and explaining berbantuan media visual non proyeksi serta kelompok kelas kedua merupakan kelas kontrol yang dibelajarkan menggunakan pembelajaran konvensional dengan pendekatan saintifik. Adapun rancangan dalam penelitian ini dapat diilustrasikan pada Gambar 1.

\begin{tabular}{|lrrl|}
\hline $\mathrm{O}_{1}$ & $\mathrm{X}$ & $\mathrm{O}_{2}$ & (eksperimen) \\
& & & \\
$\mathrm{O}_{3}$ & & $\mathrm{O}_{4}$ & (kontrol) \\
\hline
\end{tabular}

Gambar 1. Desain eksperimen menggunakan rancangan kelompok non-ekuivalen.

Setiap penelitian ilmiah selalu berhadapan dengan sumber data yang disebut populasi dan sampel. "Populasi merujuk pada keseluruhan kelompok dari mana sampel-sampel diambil" (Setyosari, 2015:220). Berdasarkan pengertian tersebut, populasi dalam penelitian ini adalah 11 kelas IV SD Negeri Gugus Letda Made Putra Kecamatan Denpasar Utara Tahun Ajaran 2017/2018. Jumlah populasi dalam penelitian ini adalah 393 siswa.

Setelah mengetahui populasi yang diteliti, langkah selanjutnya adalah menentukan sampel penelitian. "Sampel ialah sebagian dari populasi yang diambil, yang diangap mewakili seluruh populasi dan diambil dengan menggunakan teknik tertentu" (Agung, 2014:69). Pada penelitian ini teknik sampling yang digunakan adalah teknik sampel kelompok atau rumpun. Teknik ini digunakan digunakan karena populasi yang tersedia berupa unit-unit kelompok atau kelas yang telah ditentukan atau disediakan. Random dilakukan terhadap sejumlah kelas sebagai kelompok dan bukan dilakukan pengacakan terhadap individu karena tidak memungkinkan bila mengubah kelompok kelas yang telah ditentukan sebelumnya. Penentuan kelas sebagai anggota sampel dilakukan dengan menggunakan teknik undian. Setelah dilakukan pengundian diperoleh hasil dua kelas yang digunakan sebagai sampel penelitian yaitu kelas IV B di SD Negeri 2 Dangin Puri dan kelas IV A di SD Negeri 5 Tonja. Kedua kelas ini kemudian diuji kesetaraannya dengan menggunakan data nilai siswa yang diperoleh dari hasil pre-test. Pemberian pre-test selain untuk mengukur kemampuan awal siswa juga digunakan untuk mengukur ekuivalensi atau menyetarakan kelompok (Dantes, 2017).

Kesetaraan sampel diuji dengan menggunakan rumus uji-t. Sebelum melakukan uji-t untuk mencari kesetaraan, harus dilakukan uji prasyarat analisis terlebih dahulu yaitu uji normalitas sebaran data dan uji homogenitas variansi. Berdasarkan analisis yang dilakukan diketahui bahwa kedua kelompok setara, maka dilakukan pengundian kembali untuk menentukan kelompok kelas eksperimen dan kelompok kelas kontrol. Berdasarkan hasil pengundian, diperoleh kelas IV A SD Negeri 5 Tonja sebagai kelompok eksperimen yang diberi perlakuan dengan menerapkan model pembelajaran student facilitator and explaining berbantuan media visual non proyeksi, dan kelas IV B SD Negeri 2 Dangin Puri sebagai kelompok kontrol yang melaksanakan pembelajaran dengan pendekatan saintifik.

Beberapa jenis penelitian yang kita kenal selama ini, khususnya penelitian eksperimen akan selalu berhadapan dengan perihal validitas, baik validitas internal maupun eksternal. Ancaman validitas internal yang dikontrol pada penelitian ini terdiri dari karakteristik subjek dikendalikan dengan penyetaraan kelompok kelas menggunakan teknik uji-t dan dengan menggunakan kelas yang sama yakni kelas IV, sejarah dikendalikan dengan memastikan 
bahwa guru yang memberikan perlakuan pada kelompok kelas eksperimen dan kontrol memiliki kualifikasi jenjang pendidikan yang sama yakni bergelar Sarjana Pendidikan pada bidang sekolah dasar, instrumentasi dikendalikan dengan menggunakan instrumen yang telah dijudges secara teoritik dan divalidasi secara empirik, testing dikendalikan dengan pre-test dan post-test yang berbeda ditinjau dari kisi-kisi, indikator maupun struktur tes, kematangan dikendalikan dengan penggunaan waktu perlakuan yang tidak terlalu lama yaitu sebanyak 6 kali perlakuan, sikap subjek dikendalikan dengan mengupayakan agar siswa menganggap pembelajaran yang dilakukan adalah suatu hal yang rutin dengan tetap menggunakan guru kelas. Validitas eksternal yang dikontrol terdiri dari interaksi antara seleksi subjek dengan perlakuan dikendalikan dengan menggunakan teknik sampling yang tepat dan melakukan random terhadap kelas yang akan dijadikan kelompok kontrol dan eksperimen, dan interaksi setting dengan perlakuan dikendalikan dengan membatasi populasi yaitu pada kelompok kelas IV di SD Negeri Gugus Letda Made Putra Kecamatan Denpasar Utara dan memberikan materi pembelajaran yang sama yakni menggunakan buku tematik tema 8 sesuai dengan kurikulum 2013 dan silabus.

Data yang dikumpulkan dan dianalisis dalam penelitian ini adalah data kompetensi pengetahuan IPA. Metode yang digunakan dalam pengumpulan data pada penelitian ini adalah metode tes. Data tentang kompetensi pengetahuan IPA dikumpulkan melalui instrumen penelitian berupa butir tes yang dikemas menjadi suatu perangkat tes kompetensi pengetahuan IPA. Jenis tes yang digunakan dalam penelitian ini adalah tes objektif dalam bentuk pilihan ganda biasa yang meliputi 4 pilihan jawaban (a,b,c,d). Untuk setiap butir soal benar diberikan skor 1 (satu) dan untuk jawaban salah diberikan skor 0 (nol). Yusuf (2015:93) menyatakan bahwa "tes yang baik harus mampu mengukur apa yang diukur (aspek validitas) dan konsisten atau stabil dalam mengukur apa yang akan diukur (aspek reliabilitas)". Sebelum tes diberikan kepada kelompok eksperimen dan kontrol, terlebih dahulu tes diujicobakan dengan tujuan validasi butir tes. Validasi instrumen dilakukan dengan uji validitas, reliabilitas, daya beda, dan tingkat kesukaran.

Uji validitas yang digunakan dalam penelitian ini yaitu validitas isi dan validitas butir. Uji validitas isi dalam penelitian ini merujuk pada soal muatan materi IPA yang disusun sesuai dengan kompetensi dasar dan indikator yang tertera dalam Kurikulum serta dituangkan dalam bentuk kisi-kisi. Validitas butir mencakup soal yang harus diujicobakan. Untuk mengukur validitas butir tes kompetensi pengetahuan IPA dalam bentuk objektif pilihan ganda biasa digunakan rumus koefesien korelasi point biserial $\left(\gamma_{\mathrm{pbi}}\right)$. Berdasarkan hasil uji validitas butir tes dengan taraf signifikansi sebesar $5 \%$ dan responden 55 orang, diperoleh 36 butir tes yang valid dan 14 butir tes tidak valid.

Suatu instrumen dapat dikatakan mempunyai taraf reliabilitas yang tinggi jika instrumen tersebut dapat memberikan hasil yang tetap (Arikunto, 2015). Uji reliabilitas dilakukan terhadap butir soal yang valid saja, dengan demikian uji reliabilitas bisa dilakukan setelah dilakukan uji validitas. Uji reliabilitas tes yang bersifat dikotomi dan heterogen ditentukan dengan rumus Kuder Richadson (KR-20). Hasil uji reliabilitas tes kompetensi pengetahuan IPA diperoleh nilai $r_{11}$ sebesar 0,91 . Sehingga tes yang diuji layak digunakan sebagai instrumen penelitian dengan kriteria reliabilitas sangat tinggi.

Uji daya beda adalah "pengukuran sejauh mana suatu butir soal mampu membedakan siswa yang sudah menguasai kompetensi dengan siswa yang belum/kurang mengusai kompetensi berdasarkan kriteria tertentu" (Arifin, 2014:273). Tes yang dianalisis dalam uji daya beda adalah seluruh butir tes yang valid, sedangkan untuk butir tes yang tidak valid tidak digunakan. Berdasarkan perhitungan analisis daya beda tes diperoleh 11 butir tes dengan kriteria cukup, 21 butir tes dengan kriteria baik, dan 4 butir tes dengan kriteria baik sekali.

Uji tingkat kesukaran merupakan pengukuran seberapa besar derajat kesukaran suatu soal. Berdasarkan analisis tingkat kesukaran butir soal diperoleh hasil 10 soal dengan kriteria mudah, 17 soal dengan kategori sedang dan 9 soal dengan kategori sukar. Sedangkan analisis tingkat kesukaran perangkat tes diperoleh bahwa hasil perangkat tes berada dalam kategori sedang. 
Pada penelitian ini data yang dikumpulkan dianalisis menggunakan analisis statistik inferensial. "Analisis statistik inferensial adalah suatu cara pengolahan data yang dilakukan dengan jalan menerapkan rumus-rumus statistik inferensial untuk menguji suatu hipotesis penelitian yang diajukan peneliti, dan kesimpulan ditarik berdasarkan hasil pengujian terhadap hipotesis" (Agung, 2014:110). Teknik analisis data yang digunakan adalah uji hipotesis dengan menggunakan uji-t. Sebelum melaksanakan teknik analisis tersebut dibutuhkan data yang berdistribusi normal dan homogen, untuk itu dilakukan terlebih dahulu uji prasyarat analisisnya yaitu uji normalitas sebaran data dan uji homogenitas variansi.

Uji normalitas dilakukan untuk mengetahui apakah sebaran data kompetensi pengetahuan IPA siswa masing-masing kelompok berdistribusi normal atau tidak, sehingga dapat menentukan teknik analisis datanya. Uji normalitas sebaran data dalam penelitian ini menggunakan uji Kolmogorov-Smirnov. Kriteria pengujian adalah apabila nilai maksimum | $\mathrm{F}_{\mathrm{T}}-\mathrm{F}_{\mathrm{S}} \mid \leq$ nilai tabel Kolmogorov-Smirnov, maka data berdistribusi normal. Sebaliknya jika nilai maksimum $\left|\mathrm{F}_{\mathrm{T}}-\mathrm{F}_{\mathrm{S}}\right|>$ nilai tabel Kolmogorov-Smirnov, maka data tidak berdistribusi normal. Pengujian homogenitas variansi antar kelompok dimaksudkan untuk meyakinkan bahwa perbedaan yang diperoleh benar-benar berasal dari perbedaan antar kelompok dan bukan disebabkan oleh perbedaan di dalam kelompok. Uji homogenitas variansi dilakukan dengan menggunakan rumus uji $F$. Kriteria pengujian jika koefisien $F_{\text {hitung }} \leq F_{\text {tabel }}$ maka variansi sampel homogen, sedangkan jika koefisien $F_{\text {hitung }}>F_{\text {tabel }}$ maka variansi sampel tidak homogen.

Data yang telah diuji normalitas dan homogenitasnya, selanjutnya dilakukan uji hipotesis. Pada penelitian ini diuji perbedaan dari variabel terikat yakni kompetensi pengetahuan IPA antara kelompok eksperimen dan kelompok kontrol. Tujuannya adalah untuk mengetahui apakah variabel bebas yang digunakan memiliki pengaruh yang signifikan terhadap variabel terikat yang diteliti. Jika terdapat perbedaan yang signifikan variabel terikat yang diteliti pada kelompok eksperimen dan kelompok kontrol, maka dapat disimpulkan variabel bebas yang diujicobakan memiliki pengaruh yang signifikan terhadap variabel terikat. Analisis statistik yang digunakan untuk menguji hipotesis penelitian ini adalah uji beda mean (uji-t). Jenis uji-t yang digunakan menggunakan rumus polled varians dengan kriteria pengujian yaitu pada taraf signifikansi $5 \%$ dengan $d k=n_{1}+n_{2}-2$, jika $-t_{\text {tabel }} \leq t_{\text {hitung }} \leq$ $\mathrm{t}_{\text {tabel }}$ maka $\mathrm{H}_{0}$ diterima (gagal ditolak).

Besarnya efektivitas model pembelajaran student facilitator and explaining berbantuan media visual non proyeksi terhadap kompetensi pengetahuan IPA siswa dapat dilakukan dengan menghitung Koefisien Cohen's $d$. Menurut Cohen (dalam Gravetter dan Wallnau, 2014) efektivitas dapat distandarisasi dengan mengukur perbedaan rata-rata dalam satuan standar deviasi. Harga d menggambarkan besarnya efektivitas variabel bebas yang diterapkan pada kelompok eksperimen pada satu variabel terikat. Kriteria besarnya koefisien Cohen's d diklasifikasikan sebagai efek kecil jika $0<d<0,2$ (selisih rata-rata kurang dari 0,2 standar deviasi), efek sedang jika 0,2 $<\mathrm{d}<0,8$ (selisih rata-rata sekitar 0,5 standar deviasi), dan efek besar jika $d>0,8$ (selisih rata-rata lebih dari 0,8 standar deviasi).

\section{Hasil dan Pembahasan}

Objek dalam penelitian ini adalah kompetensi pengetahuan IPA. Terdapat 4 kelompok data dalam peneliian ini yaitu data pre-test kelompok eksperimen, data pre-test kelompok kontrol, data post-test kelompok eksperimen, dan data post-test kelompok kontrol. Data pretest digunakan untuk penyetaraan kedua kelompok sebelum diberikan perlakuan. Hasil pretest kedua kelompok sampel dapat dilihat pada grafik steam and leaf pada gambar 2

\begin{tabular}{c|c|c}
$\begin{array}{c}\text { SD N } 2 \text { Dangin Puri } \\
\text { Leaves }\end{array}$ & $\begin{array}{c}\text { Pre-Test } \\
\text { Steam }\end{array}$ & $\begin{array}{c}\text { SD N 5 Tonja } \\
\text { Leaves }\end{array}$
\end{tabular}




\begin{tabular}{r|l|l}
- & 0 & - \\
- & 1 & - \\
- & 2 & - \\
- & 3 & - \\
3300 & 4 & 00377 \\
777773 & 5 & 0377 \\
777330 & 6 & 03777 \\
7777777330 & 7 & 0000000000003333777 \\
333000 & 8 & 000337 \\
- & 9 & 03
\end{tabular}

Tes kompetensi pengetahuan IPA yang digunakan sebagai instrumen post-test berjumlah 36 butir soal pilihan ganda biasa yang telah diuji validitas, reliabilitas, daya beda dan tingkat kesukaran. Diketahui data post-test kelompok eksperimen berpusat di sekitar nilai 75,37 dengan penyimpangan skor terhadap rata-rata sebesar 13,47 dan nilai minimum 44 serta nilai maksimum 97 . Pada kelompok kontrol diketahui bahwa data berpusat di sekitar nilai 68,25 dengan penyimpangan skor terhadap rata-rata sebesar 14,78 , nilai minimum 44 serta nilai maksimum 94.

Sebelum dilakukan pengujian hipotesis, terlebih dahulu dilakukan uji prasyarat analisis yang meliputi uji normalitas dan uji homogenitas variansi. Hasil uji normalitas sebaran data post-test kompetensi pengetahuan IPA pada kelompok eksperimen diperoleh nilai maksimum $\left|\mathrm{F}_{\mathrm{T}}-\mathrm{F}_{\mathrm{S}}\right|=0,148$ dan nilai tabel Kolmogorov-Smirnov untuk taraf signifikansi 5\% $(\alpha=0,05)=0,212$ karena nilai maksimum $\left|F_{T}-F_{S}\right|<$ nilai tabel Kolmogorov-Smirnov maka data berdistribusi normal. Sedangkan hasil uji normalitas sebaran data post-test kelompok kontrol diperoleh nilai maksimum $\left|\mathrm{F}_{\mathrm{T}}-\mathrm{F}_{\mathrm{S}}\right|=0,142$ dan nilai tabel Kolmogorov-Smirnov untuk taraf signifikansi $5 \%(\alpha=0,05)=0,234$. Karena nilai maksimum $\left|F_{T}-F_{S}\right|<$ nilai tabel Kolmogorov-Smirnov maka data berdistribusi normal.

Pada uji homogenitas diperoleh $F_{\text {hitung }}=1,20$ dan nilai $F_{\text {tabel }}=1,74$ pada taraf signifikansi $5 \%$ dengan derajat kebebasan pembilang $=31$ dan derajat kebebasan penyebut $=40$. Karena $F_{\text {hitung }}=1,20<F_{\text {tabel }}=1,74$, maka data kedua kelompok memiliki variansi yang homogen.

Berdasarkan uji prasyarat analisis yang telah dilakukan, diperoleh data kedua kelompok sampel berdistribusi normal dan variansi homogen, maka dilakukan uji statistik menggunakan uji beda mean (uji-t) dengan rumus polled varians.

\section{Simpulan dan Saran}

Berdasarkan rata-rata skor post-test siswa pada kelompok eksperimen yaitu sebesar 75,37 dan rata-rata siswa pada kelompok kontrol sebesar 68,25. Kriteria pengujian yaitu pada taraf signifikansi $5 \%$ dengan $\mathrm{dk}=\mathrm{n}_{1}+\mathrm{n}_{2}-2$, jika harga $-\mathrm{t}_{\text {tabel }} \leq \mathrm{t}_{\text {hitung }} \leq \mathrm{t}_{\text {tabel }}$ maka $\mathrm{H}_{0}$ diterima. Berdasarkan analisis uji-t diperoleh $t_{\text {hitung }}=2,147$ sedangkan pada taraf signifikansi $5 \%$ dengan derajat kebebasan $(\mathrm{dk}=41+32-2)=71$ diperoleh $\mathrm{t}_{\text {tabel }}=1,994$. Karena harga $t_{\text {hitung }}>t_{\text {tabel }}$ maka dapat disimpulkan $\mathrm{H}_{0}$ ditolak (gagal diterima). Hal ini berarti terdapat perbedaan yang signifikan kompetensi pengetahuan IPA antara kelompok eksperimen dan kelompok kontrol. Sehingga dapat disimpulkan bahwa terdapat pengaruh yang signifikan model pembelajaran student facilitator and explaining berbantuan media visual non proyeksi terhadap kompetensi pengetahuan IPA siswa kelas IV SD Gugus Letda Made Putra Kecamatan Denpasar Utara tahun ajaran 2017/2018.

Setelah dilakukan pengujian hipotesis, langkah selanjutnya adalah mencari besarnya efek untuk melihat efektivitas model pembelajaran sehingga menyebabkan perbedaan yang signifikan. Efektivitas dibutuhkan karena signifikasi statistik tidak memberikan informasi yang cukup berarti terkait dengan besarnya perbedaan kompetensi pengetahuan IPA yang terjadi pada kelompok eksperimen dan kontrol. Maka dari itu efektivitas penting untuk menandakan seberapa besar perbedaan yang dihasilkan oleh perlakuan pada kelompok eksperimen. Perhitungan efektivitas dilakukan dengan menentukan Koefisien Cohen's $d$. Berdasarkan 
hasil perhitungan efektivitas, diperoleh nilai Koefisien Cohen's $d=0,51$. Sesuai dengan kriteria efektivitas menurut Cohen, nilai d sebesar 0,51 termasuk dalam kategori efek sedang. Sehingga, dapat dinyatakan bahwa model pembelajaran student facilitator and explaining berbantuan media visual non proyeksi yang diterapkan pada kelompok eksperimen memberikan efek dengan kategori sedang terhadap kompetensi pengetahuan IPA siswa.

Berdasarkan hasil temuan pada kedua kelompok diperoleh jika kedua kelompok yang awalnya memiliki kemampuan setara, lalu setelah diberikan perlakuan pada kelompok eksperimen maka perolehan nilai kompetensi pengetahuan IPA mengalami perbedaan yang signifikan. Kompetensi pengetahuan IPA siswa pada kelompok eksperimen lebih baik apabila dibandingkan dengan kompetensi pengetahuan IPA siswa pada kelompok kontrol. Hal ini dapat dilihat juga dari rata-rata siswa kelompok eksperimen dan siswa kelompok kontrol. Perbedaan kompetensi pengetahuan IPA tersebut disebabkan oleh perlakuan berupa model pembelajaran student facilitator and explaining berbantuan media visual non proyeksi yang diterapkan pada kelompok eksperimen.

Pembelajaran muatan materi IPA pada tema 8 (Daerah Tempat Tinggalku) di kelompok eksperimen berjalan dengan baik dan kondusif. Walaupun pada pertemuan pertama, hanya sedikit dari kelompok siswa yang bersedia menjadi facilitator. Hal ini terjadi karena pelaksanaan proses pembelajaran mengalami sedikit hambatan yakni siswa merasa malu dalam mempresentasikan materi pembelajaran sehingga keaktifan siswa masih belum maksimal. Hambatan itu terjadi karena siswa masih merasa asing dengan model pembelajaran student facilitator and explaining berbantuan media visual non proyeksi yang digunakan, dimana model pembelajaran ini menuntut keaktifan siswa sehingga membutuhkan penyesuaian dan guru harus membimbing setiap siswa.

Pada pertemuan kedua dan ketiga siswa mulai berminat dan terbiasa dengan model pembelajaran yang diterapkan. Minat siswa untuk menjadi facilitator mulai bertambah. Siswa mulai mengerti alur pembelajaran yang dilakukan, yakni diawali dengan guru menyajikan atau mendemosntrasikan materi secara garis-garis besar di depan kelas, kemudian siswa diberi kesempatan untuk memahami materi, setelah itu siswa diberi kesempatan untuk menjelaskan materi sesuai dengan ide atau gagasannya kepada teman-temannya, dan diakhiri dengan penyampaian materi secara keseluruhan kepada siswa.

Pada pertemuan-pertemuan berikutnya, siswa sudah benar-benar paham dengan model pembelajaran yang digunakan. Ketika guru memberi kesempatan siswa untuk menjelaskan materi di depan kelas, seluruh kelompok siswa nampak sudah siap dan mampu berperan aktif dalam mengungkapkan ide atau pendapatnya terkait materi yang dibahas. Siswa tidak malu-malu lagi untuk menjelaskan materi di depan teman-temannya.

Temuan penelitian yang menunjukkan bahwa model pembelajaran student facilitator and explaining berbantuan media visual non proyeksi berpengaruh secara signifikan terhadap kompetensi pengetahuan IPA dikarenakan oleh beberapa hal diantaranya model pembelajaran ini memberi kesempatan kepada siswa untuk menyampaikan materi pembelajaran yang memuat berbagai informasi sesuai dengan gagasan atau pendapatnya, sehingga siswa menjadi lebih paham, aktif dan antusias dalam proses pembelajaran. Maka dari itu siswa harus memiliki kesiapan, keberanian serta keinginan yang kuat untuk mampu menyampaikannya di depan kelas. Keterlibatan yang aktif dengan gagasan-gagasan tersebut mendorong aktifitas siswa untuk berpikir, menemukan, menganalisa, serta menyimpulkan pemahaman konsep kemudian mengintegrasikan dengan konsep yang telah mereka miliki sebelumnya sehingga pembelajaran menjadi lebih bermakna dan menyenangkan. Selain itu model ini juga memberi kesempatan kepada siswa untuk saling bekerjasama dalam memecakan suatu masalah dalam pembelajaran, siswa menjadi lebih bertanggung jawab dengan tugasnya masing-masing, dan siswa pun mendapat kesempatan untuk saling bertukar pikiran dengan temannya.

Pelaksanaan model pembelajaran student facilitator and explaining dalam penelitian ini dipadukan dengan penggunaan media visual non proyeksi untuk memudahkan siswa dalam memahami materi yang disampaikan, karena hakikatnya media visual non proyeksi mampu menerjemahkan ide-ide atau pembelajaran yang abstrak menjadi lebih nyata sehingga 
membuat siswa lebih cepat dan mudah memahami suatu materi yang diajarkan. Sehingga kegiatan pembelajaran dengan menggunakan model student facilitator and explaining berbantuan media visual non proyeksi menjadi lebih bermakna, menyenangkan, serta berpengaruh positif terhadap kompetensi pengetahuan IPA siswa.

Sedikit berbeda dengan pembelajaran pada kelompok eksperimen, kegiatan pembelajaran yang berlangsung pada kelompok kontrol kurang optimal karena hanya mengacu pada lima pengalaman belajar yaitu mengamati, menanya, mengumpulkan informasi, mengasosiasi dan mengomunikasikan. Keadaan siswa pada saat proses pembelajaran berlangsung terlihat kurang aktif jika dibandingkan dengan kelompok eksperimen. Siswa kurang diberi kesempatan untuk bertukar pikiran dengan temantemannya. Kegiatan siswa lebih banyak dilatih untuk membuat dan menjawab soal-soal yang diberikan kemudian mempertanggung jawabkannya

Berdasarkan uraian tersebut, pembelajaran meggunakan model pembelajaran pada penelitian ini memiliki keunggulan, yakni dapat membangkitkan kecerdasan melalui aktivitas intelektual dan membangkitkan daya serap siswa terhadap materi dalam proses pembelajaran melalui suasana belajar yang menyenangkan. Model ini juga efektif dalam memicu motivasi antar siswa untuk menjadi yang terbaik saat menjelaskan kembali materi pembelajaran di depan teman-temannya.

Model pembelajaran student facilitator and explaining berbantuan media visual non proyeksi memiliki efektivitas dengan kategori efek sedang. Hal tersebut dapat terjadi karena diluar model pembelajaran yang diterapkan terdapat faktor-faktor lain yang juga berpengaruh terhadap kompetensi pengetahuan IPA siswa.

\section{SIMPULAN DAN SARAN}

Rata-rata skor post-test siswa pada kelompok eksperimen sebesar 75,37 dan ratarata siswa pada kelompok kontrol sebesar 68,25. Berdasarkan hasil analisis uji-t diperoleh $t_{\text {hitung }}=2,147$ sedangkan pada taraf signifikansi $5 \%$ dan $\mathrm{dk}=71$ diperoleh nilai $t_{\text {tabel }}=1,994$. Oleh karena $t_{\text {hitung }}=2,147>t_{\text {tabel }}=1,994$ maka $H_{0}$ ditolak (gagal diterima). Sehingga terdapat perbedaan yang signifikan kompetensi pengetahuan IPA antara kelompok eksperimen dan kelompok kontrol. Maka dapat disimpulkan bahwa model pembelajaran student facilitator and explaining berbantuan media visual non proyeksi berpengaruh secara signifikan terhadap kompetensi pengetahuan IPA IV SD Gugus Letda Made Putra Kecamatan Denpasar Utara Tahun Ajaran 2017/2018. Efektivitas model pembelajaran student facilitator and explaining berbantuan media visual non proyeksi dilakukan dengan menghitung Koefisien Cohen's $d$. Berdasarkan hasil perhitungan, diperoleh nilai d sebesar 0,51 dengan kategori efek sedang. Sehingga dapat disimpulkan bahwa model pembelajaran student facilitator and explaining berbantuan media visual non proyeksi memberikan efek dengan kategori sedang terhadap kompetensi pengetahuan IPA siswa kelas IV SD Gugus Letda Made Putra Kecamatan Denpasar Utara tahun ajaran 2017/2018.

Berdasarkan hasil penelitian, pembahasan dan simpulan, maka dapat diajukan saran kepada guru, kepala sekolah dan peneliti lain. Kepada guru disarankan agar lebih kreatif dalam memberikan fasilitas berupa sumber belajar dan kesempatan yang lebih besar bagi siswa dalam proses pembelajaran dengan menggunakan model-model pembelajaran yang inovatif khususunya model pembelajaran student facilitator and explaining berbantuan media visual non proyeksi, sehingga tercipta pembelajaran bermakna bagi siswa. Kepada kepala sekolah disarankan agar dapat menggunakan hasil penelitian ini sebagai pendukung sumber belajar dalam mengembangkan proses pembelajaran dengan menciptakan suasana pembelajaran yang menyenangkan di sekolah sehingga sekolah mampu menghasilkan output yang berkualitas. Kepada peneliti lain disarankan agar hasil penelitian ini digunakan sebagai referensi untuk melaksanakan penelitian selanjutnya serta menemukan inovasi dalam merancang kegiatan pembelajaran lainnya yang bermakna bagi siswa. 


\section{Daftar Pustaka}

Agung, A. A. G. 2014. Buku Ajar Metodologi Penelitian Pendidikan. Yogyakarta: Aditya Media Publishing.

Arifin, Zainal. 2014. Evaluasi Pembelajaran. Bandung: PT Remaja Rosdakarya Offset.

Arikunto, Suharsimi. 2015. Dasar-Dasar Evaluasi Pendidikan. Jakarta: Bumi Aksara.

Dantes, N. 2017. Desain Eksperimen dan Analisis Data. Depok: Rajawali Pers.

Gravetter, Frederick J dan Larry B. Wallnau. 2014. Essentials of Statistics for the Behavioral Sciences. Eight Edition. Belmont, CA: Wadsworth.

Hamalik, Oemar. 2014. Kurikulum dan Pembelajaran. Jakarta: Bumi Aksara.

Kosasih, E. 2014. Strategi Belajar dan Pembelajaran Implementasi Kurikulum 2013. Bandung: Yrama Widya.

Kurniasih, Imas dan Berlin Sani. 2015. Ragam Pengembangan Model Pembelajaran untuk Peningkatan Profesionalitas Guru. Yogyakarta: Kata Pena.

Musfiqon, 2012.Pengembangan Media dan Sumber Pembelajaran. Jakarta: PT. Prestasi Pustakarya.

Samatowa, Usman. 2016. Pembelajaran IPA di Sekolah Dasar. Jakarta: PT. Indeks.

Setyosari, Punaji. 2015. Metode Penelitian Pendidikan dan Pengembangan. Jakarta: Prenadamedia Group.

Shoimin, Aris. 2014. 68 Model Pembelajaran Inovatif dalam Kurikulum 2013. Yogyakarta: Arruzz Media.

Susanto, Ahmad. 2013. Teori Belajar dan pembelajaran di Sekolah Dasar. Jakarta: Prenadamedia Group.

Wati, Ega Rima. 2016. Ragam Media Pembelajaran Visual - Audio Visual - Komputer-Power Point-Internet-Interactive Video. Yogyakarta: Kata Pena.

Wisudawati, Asih Widi dan Eka Sulistyowati. 2014. Metodologi Pembelajaran IPA. Jakarta: Bumi Aksara.

Yusuf, Muri. A. 2015. Asesmen dan Evaluasi Pendidikan Pilar Penyedia Informasi dan Kegiatan pengendalian Mutu Pendidikan. Jakarta: Prenadamedia Group.

Kumaidi. 2005. Pengukuran Bekal Awal Belajar dan Pengembangan Tesnya. Jurnal IImu Pendidikan. Jilid 5, No. 4,

Kuntoro, T. 2006. Pengembangan Kurikulum Pelatihan Magang di STM Nasional Semarang: Suatu Studi Berdasarkan Dunia Usaha. Tesis tidak diterbitkan. Semarang: PPS UNNES

Pitunov, B. 13 Desember 2007. Sekolah Unggulan Ataukah Sekolah Pengunggulan ? Majapahit Pos, hlm. 4 \& 11

Waseso, M.G. 2001. Isi dan Format Jurnal IImiah. Makalah disajikan dalam Seminar Lokakarya Penulisan artikel dan Pengelolaan jurnal IImiah, Universitas Lambungmangkurat, 9-11Agustus 